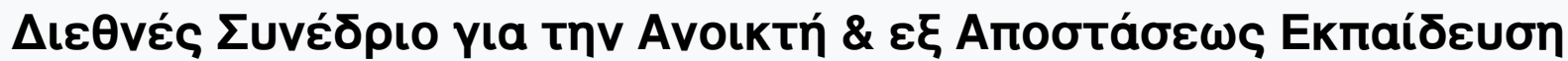

Tón. 5, Ap. 1A (2009)

Open and Distance Education for Global Collaboration \& Educational Development

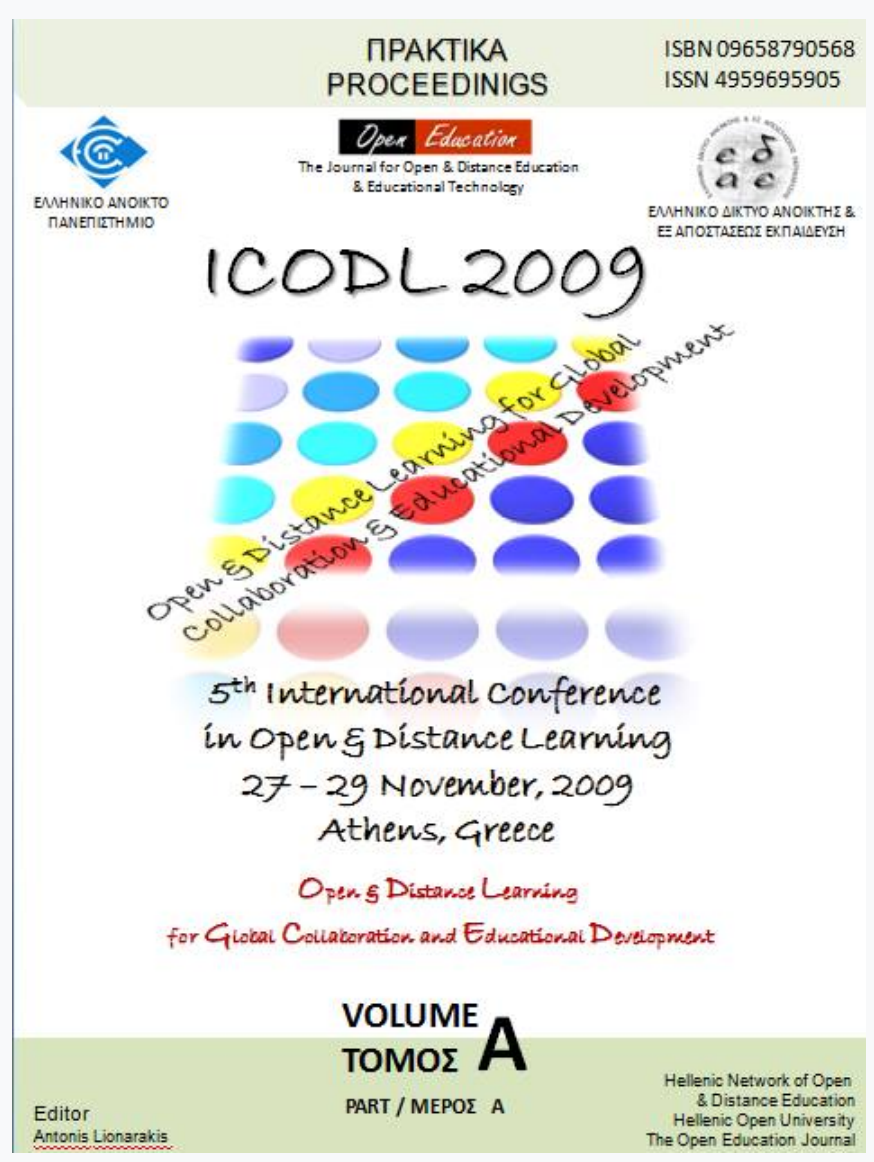

Emerging paradigm of management and training in open university in Pakistan

Nabi Bux JUMANI, Muhammad ATHAR HUSSAIN, Shahinshah BABAR KHAN

doi: $\underline{10.12681 / \text { icodl. } 486}$ 


\title{
Emerging paradigm of management and training in open university in Pakistan
}

\author{
Dr. Nabi Bux JUMANI \\ Assistant Professor \\ Allama Iqbal Open University Islamabad, \\ Pakistan \\ nbjumani@aiou.edu.pk
}

\author{
Muhammad ATHAR HUSSAIN \\ PhD scholar \\ International Islamic University Islamabad, \\ Pakistan \\ athar_iiu@yahoo.com
}

\author{
Shahinshah BABAR KHAN \\ M.Phil Research Fellow \\ Allama Iqbal Open University Islamabad, Pakistan
}

\begin{abstract}
Allama Iqbal Open University (AIOU) is a unique institution in Pakistan because of its philosophy, system, approach, functions and overall structure. AIOU is a Distance Education institution, which provides multi disciplinary education from basic to doctoral level programs. The university employs non-formal method of correspondence, radio and television broadcasts, special textbooks and reading materials prepared on self-learning basis, part-time teachers (tutors) engaged nearest to the student's residences.

This paper has outlined a training model for tutors in terms of job competencies and training needs in distance learning. A questionnaire was administered to 50 tutors of Rawalpindi district. The tutors were of M.ED/M.A education program semester spring 2007, Allama Iqbal Open University Pakistan. The collected data was analyzed statistically. Findings showed that the respondents agreed that tutors need training in developing unit objectives, selecting students' activities and understanding selfassessment questions. They also need training in coordinating with regional office, counseling and motivating the students, marking and monitoring of assignments, preparing results and use of A.V aids. Data indicated that training of tutors in these areas would lead them to competency in academic skills, professional skills, orientation with distance learning and knowledge of psychology. According to the responses, the training in the proposed model would alsos result in knowing evaluation techniques, educational effective social skills and students' promotion.

It was recommended that training for AIOU tutors should be arranged according to the 'Inputs' of the Training Model. The training managers should be aware of the job competencies according to the 'Outputs' of the Training Model.
\end{abstract}

\section{Literature}

Distance education mode is the most popular way of learning all over the world. In developing and developed countries, this mode getting more place than traditional learning. With the passage of time, to cope with the challenges, education is the only 
path which takes a nation towards its destination. "Distance education is the system of education in which there is no face to face relationship between the teacher and taught, but they are linked through different media as print, Radio, T.V etc".(Kaur,1996). The term distance/correspondence education must stress that it would include any planned and regular educational provision where there is a distance between teacher, instructor or educator on the one hand, and student, learner or receptive audience on the other. It must mean primarily a distance in place and distance in time, whatever other interpretations, psychological or social, might be through to arise from the first two aspects of distance.(Dodds, T. (1978,p.246) .

Distance learning is the method in which teacher and students at a distance from each other, and remain in contact with each other through media and used additional ways. The aim of the distance education to educate maximum individuals of a nation because formal institutions cannot fulfill the demands of the present time. For each nation it is very difficult to educate its mass through formal system, that is why distance mode becoming more and more attraction. For distance education different techniques/methodologies are used so that the result vector may be able to prepare such individuals who can play their role in society actively. In distance mode it is kept in mind to facilitate the students at their doorsteps.

According to Moore \& Kearsley ( 1996, p.2).

Distance education is planned learning that normally occurs in a different place from teaching and as a result requires special techniques of course design, special instructional techniques, special method of communication by electronic and other technology, as well as special organizational and administrative arrangements.

Distance education is present in all over the world with different names in different countries. The methods used for distance education almost same with some change, but the aim of distance education all over the world is the same I,e to educate the individuals .

Tutor is one of the important element of distance education. According to Harris (1975, p.18) the distance tutor: "Is the voice and the personality of the correspondence method. It is primarily on the tutor that method ultimately depends for on its efficiency and its humanity." Koul, B.N (1995,p.277) describes the role of tutor. The tutor has to stretch his reach fully he must understand each and every student, and unlike a classroom teacher who address the abstract average student of his class, the distance tutor has to address every student individually. And only way of addressing his students is to write comments on the answer scripts. This makes his task much more difficult and challenging than that of the classroom teacher. Sewart, D .et al (1983,p.334) indicates that the correspondence marking is the chief method by which a tutor teaches his students .but most courses offer a limited number of face-to-face tutorials which course tutor have to plan and give. It must be realized that face-to-face tuition within the open university does not try to assume the function it has in most colleges, polytechnics and universities, where it is of prime importance. 
One of the main component of the distance learning is tutor. Tutor is the person who can guide/facilitate students in their study and also show them the right path. Sewart, D.et al (1983,p.334) further says that the class tutorial in the Open University does have an importance, if restricted part to play in the teaching system. Its original intention was that it should be remedial and supportive in nature. The main role of the tutor here is not to develop new themes and ideas, but to ensure that students understand the ideas and arguments in the course units and broadcasts and to remedy student's academic weaknesses. There are many functions of a tutors, like guiding students, helping students , supervision of students.

Bernadette, Robinson (1981, p.150) explain various functions of a tutor as given below:

1. Commenting on student's written work.

2. Marking and assigning grades to students; written work.

3. Helping students to understand course material through discussions.

4. Answering student's queries about the system.

5. Helping students to plan their work.

6. Organizing self-help groups or study circles.

7. Conducting face-to-face or telephone discussion.

8. Demonstrating and supervising practical or project work.

9. Teaching at a residential school or personal contact progrmme.

10. Keeping records of students' progress.

11. Delivering a lecture and giving feedback on course material and students' problems to the local centre co-coordinator, or counselor or course writers.

12. Negotiating with the institution on students' behalf when certain problems occur.

In Pakistan Allama Iqbal Open University, Islamabad (AIOU) introduced the distance and non-formal education. This university was formally established at Islamabad in June 1974, after passing the people's Open University act by the national assembly of Pakistan. Its origin lay in the education policy (1972-80) document stated below: A people's Open University will therefore be established to provide part -time education facilities through corresponding courses, tutorials, seminars, radio broad-cast and other mass communication media. Allama Iqbal Open University is one of the largest institutions in South Asia. For effective teaching learning process AIOU appoints tutors who guide the student, solve their academic problems.

The term competency standard refers to "a combination of attributes underlying some aspects of successful performance" (Gonczi et al., 1990, p.9).Messick (1984, p.227) clarifies this concept in following words:

Competence refers to what a person knows and can do under ideal circumstances whereas performance refers to what is actually done under existing circumstances. Competence embraces the structure of knowledge and abilities, whereas performance subsumes as well, the processes of accessing and utilizing those structures and a host of affective, motivational, attentional and stylistic factors that influence the ultimate responses. 
Education effects on all the characteristics of life, quality education produce good citizens and helps in growing economy of a nation, while low standard education produce only persons who cannot play their role effectively towards the progress of a nation. For quality education competency is the base element. The statement of the problem is "Emerging Paradigm of Management and Training in Open University in Pakistan". Keeping in view the above statement chalk out a training model for tutors in terms of job competencies and training needs in distance learning

\section{Terms used}

Audio-Video aids(A.V.Aids): The devices which have an impact on the eyes and ears of the learners and enhance the effectiveness of the teaching-learning process.

Educational Technologies: The technologies used in education, which are helpful for advancing the learning process.

\section{The study}

The population for the present study was the tutors Appointed by Allma Iqbal Open University. A total of 50 tutors of M.ED/M.A education program semester spring 2007, Allama Iqbal Open University Pakistan were the sample for the present study. The sample was randomly selected from Rawalpindi. A questionnaire consisting of two types of items, that is, 15 items relating to job competencies of tutors and 12 items relating to their training was administered. After collecting data, each statement of the questionnaire was tested by applying chi-square technique at significance level 0.05. There were five options for each question, i,e Strongly Agree, Agree, Uncertain, Disagree, Strongly Disagree. The respondents were asked to select the best option according to their choice.

The tutors believed that they have clear vision of distance education and they guide their students in the light of their experience. They also believe that use of educational technologies enhance the effectiveness but they do not know the use of educational technologies.

\section{Results}

There were two aspects of data i.e. management of tutoring and training of tutors.

\section{Management of tutoring:}

\begin{tabular}{|l|l|c|r|r|r|r|r|l|}
\hline Item \# & \multicolumn{1}{|c|}{ Statement } & SA & A & UNC & DA & SDA & $\chi^{2}$ & $\begin{array}{l}\text { Significant } \\
\text { / Non- } \\
\text { Significant }\end{array}$ \\
\hline 1 & $\begin{array}{l}\text { Tutors have clear vision about } \\
\text { counseling/guiding of } \\
\text { students. }\end{array}$ & 5 & 20 & 6 & 10 & 9 & 14.2 & Significant \\
\hline 2 & \begin{tabular}{l} 
Tutors are well aware abou \\
\hline
\end{tabular} & 13 & 18 & 9 & 10 & 0 & 17.4 & Significant \\
\hline
\end{tabular}




\begin{tabular}{|c|c|c|c|c|c|c|c|c|}
\hline & the system of AIOU. & & & & & & & \\
\hline 3 & $\begin{array}{l}\text { Tutors checks assignment wel } \\
\text { in time and give remarks. }\end{array}$ & 21 & 25 & 4 & 0 & 0 & 58.2 & Significant \\
\hline 4 & $\begin{array}{l}\text { Tutors provide extr } \\
\text { counseling on request } \mathrm{o} \\
\text { students. }\end{array}$ & 15 & 18 & 8 & 9 & 0 & 19.4 & Significant \\
\hline 5 & $\begin{array}{l}\text { Tutors arranged tutorial } \\
\text { regularly. }\end{array}$ & 9 & 26 & 10 & 5 & 0 & 38.7 & Significant \\
\hline 6 & $\begin{array}{l}\text { Tutors behave to students in } \\
\text { friendly way. }\end{array}$ & 12 & 20 & 12 & 6 & 0 & 24.4 & Significant \\
\hline 7 & $\begin{array}{l}\text { Students are aware abou } \\
\text { distance learning. }\end{array}$ & 12 & 15 & 9 & 10 & 4 & 6.6 & $\begin{array}{l}\text { Non- } \\
\text { Significant }\end{array}$ \\
\hline 8 & $\begin{array}{l}\text { Tutors know the use o } \\
\text { Educational Technology. }\end{array}$ & 6 & 15 & 9 & 12 & 8 & 5.0 & $\begin{array}{l}\text { Non- } \\
\text { Significant }\end{array}$ \\
\hline 9 & $\begin{array}{l}\text { Tutors used A.V aids in } \\
\text { tutorials. }\end{array}$ & 8 & 12 & 15 & 5 & 10 & 5.8 & $\begin{array}{l}\text { Non- } \\
\text { Significant }\end{array}$ \\
\hline 10 & $\begin{array}{l}\text { Tutors submit results o } \\
\text { assignments in regional offic } \\
\text { in time. }\end{array}$ & 35 & 15 & 0 & 0 & 0 & 95.0 & Significant \\
\hline 11 & $\begin{array}{l}\text { Tutors have basic concepts o } \\
\text { their subjects. }\end{array}$ & 15 & 30 & 5 & 0 & 0 & 72.5 & Significant \\
\hline 12 & $\begin{array}{l}\text { Tutors satisfy the students it } \\
\text { tutorials regarding thei } \\
\text { questions about distanc } \\
\text { learning. }\end{array}$ & 6 & 30 & 4 & 10 & 0 & 55.2 & Significant \\
\hline 13 & $\begin{array}{l}\text { Tutors provide extra coachin } \\
\text { other than tutorials. }\end{array}$ & 5 & 25 & 10 & 10 & 0 & 35.0 & Significant \\
\hline 14 & $\begin{array}{l}\text { Tutors know about th } \\
\text { organization of class. }\end{array}$ & 12 & 18 & 0 & 15 & 5 & 21.8 & Significant \\
\hline 15 & $\begin{array}{l}\text { During tutorials tutors car } \\
\text { about the facilities for studen } \\
\text { at study centre. }\end{array}$ & 5 & 32 & 2 & 10 & 1 & 65.4 & Significant \\
\hline
\end{tabular}

$\mathrm{df}=4 \quad$ Table value of $\chi^{2}$ at level $0.05=9.488$

The above table shows that the respondents were agreed that the tutors have clear vision about counseling of students and are well aware about the system of AIOU. They check the assignments of the students and give remarks. The respondents were disagreeing with statements at serial number 7,8 and 9. They were of the opinion that students do not know the importance of distance education. The tutors are not good users of educational technology; the reason may be is that there is lack of educational technologies in the institutions so they do not use these technologies in the tutorials.

\section{Training of tutors:}

\begin{tabular}{|l|l|r|r|r|r|r|r|c|}
\hline Item \# & Statement & SA & A & UNC & DA & SDA & $\chi^{2}$ & Significant \\
\hline \multicolumn{6}{|c|}{ SECTION A: theoretical papers, original research and scientific articles } \\
\hline
\end{tabular}




\begin{tabular}{|c|c|c|c|c|c|c|c|c|}
\hline & & & & & & & & $\begin{array}{l}\text { / Non- } \\
\text { Significant }\end{array}$ \\
\hline 16 & $\begin{array}{l}\text { Tutors need more trainin } \\
\text { about the system of AIOU. }\end{array}$ & 24 & 18 & 8 & 0 & 0 & 46.4 & Significant \\
\hline 17 & $\begin{array}{l}\text { Special workshops/refreshe } \\
\text { courses are needed fo } \\
\text { updating tutors. }\end{array}$ & 12 & 22 & 8 & 4 & 4 & 22.4 & Significant \\
\hline 18 & $\begin{array}{l}\text { Tutors need training in use o } \\
\text { educational technology. }\end{array}$ & 20 & 30 & 0 & 0 & 0 & 80.0 & Significant \\
\hline 19 & $\begin{array}{l}\text { Tutors needed training abou } \\
\text { world wide scenario o } \\
\text { distance education }\end{array}$ & 30 & 18 & 2 & 0 & 0 & 72.8 & Significant \\
\hline 20 & $\begin{array}{l}\text { Tutors needed training o } \\
\text { psychology for effectin } \\
\text { teaching. }\end{array}$ & 12 & 18 & 5 & 8 & 7 & 10.6 & Significant \\
\hline 21 & $\begin{array}{l}\text { Tutors needed workshops fo } \\
\text { getting competency. }\end{array}$ & 12 & 26 & 2 & 10 & 0 & 42.4 & Significant \\
\hline 22 & $\begin{array}{l}\text { Tutors needed training abou } \\
\text { how to stimulate learners fo } \\
\text { education. }\end{array}$ & 16 & 26 & 8 & 0 & 0 & 49.6 & Significant \\
\hline 23 & $\begin{array}{l}\text { Tutors needed training o } \\
\text { different techniques used in } \\
\text { distance learning }\end{array}$ & 15 & 35 & 0 & 0 & 0 & 95.0 & Significant \\
\hline 24 & $\begin{array}{l}\text { Tutors needed training o } \\
\text { supervisory/management. }\end{array}$ & 18 & 25 & 7 & 0 & 0 & 49.8 & Significant \\
\hline 25 & $\begin{array}{l}\text { Tutors needed training fo } \\
\text { lesson planning. }\end{array}$ & 10 & 7 & 8 & 15 & 10 & 3.8 & $\begin{array}{l}\text { Non- } \\
\text { Significant }\end{array}$ \\
\hline 26 & $\begin{array}{l}\text { Tutors needed training to } \\
\text { promote interaction witl } \\
\text { community. }\end{array}$ & 12 & 18 & 10 & 5 & 5 & 11.8 & Significant \\
\hline 27 & $\begin{array}{l}\text { Tutors needed training abou } \\
\text { issues and trends in distanc } \\
\text { education. }\end{array}$ & 9 & 28 & 10 & 3 & 0 & 47.4 & Significant \\
\hline
\end{tabular}
$\mathrm{df}=4 \quad$ Table value of $\chi^{2}$ at level $0.05=9.488$

The above table shows that the respondents were agreed with all the statements.. The tutors think that they need more training about distance education system in Pakistan and in the international scenario, and for this purpose special workshops may be sarranged for the tutors in which they learn how to stimulate the students for education and about the use different techniques used in distance education system. The tutors were of opinion that they do not needed training for lesson planning because they prepare lessons for their regular classes in their institutions, this experience helps them for their tutoring job. 


\section{Findings}

1. Tutors have vision how to guide students for educational matters.

2. Tutors are well aware about the system of AIOU, and check assignments in time.

3 Tutors provide counseling to students and extra counseling on request of Students and deal with them like friends.

4. Students of distance learning are not well aware about distance education.

5. Tutors do not use A.V aids in tutorials.

6 Tutors submit the result of assignments in time.

$7 \quad$ Tutors are competent in their subject area.

8. Tutors have knowledge how to organize class for effective teaching/learning

9. Tutors do not use A.V aids in tutorials

10. Tutors submit the results of assignment in time to the regional offices.

11. Tutors confirm that they have basic knowledge of their subject.

12. Tutors provide counseling and extra help to the learners.

13. Tutors have knowledge about class management.

14. Tutors need training about system of AIOU

15 Tutors need special refresher courses for updating.

16. Tutors need training about use of Information and communication technology.

17. Tutors need training for the world wide scenario of distance education more over how to stimulate the learners

\section{Discussion}

Tutors are the important element of the distance education. Performance of distance learners to some extent depend on the guidance provided them by tutors. Tutors confirm that they have knowledge about the system of AIOU. Tutors were agreed upon that they provide extra coaching to students on request and moreover, they try to facilitate the students on study centre. Tutors also confirm that they have knowledge in their subject. Now a days technology is playing its role in the field of education in different forms .Tutors give information that they have not command over the use of educational technology, they donot use these educational A.V ads in education. Tutors suggest that they should be trained in computer so that they become able to use educational technology for better results. For smooth running, it is necessary all work should be dome in time and tutors provided view that they submit the result of assignment in time so that students can get their results in time. The role of community for development of eduction is crucial, and with the passage of time its importance is increasing rapidly, tutors inform they donot know how to involve the community for uplift the standard of distance education and suggest that they should be trained how to communicate with society for improvement the standard of distance education. Up dating in every field can increase the quality of the work tutors inform that they must be trained about new issues and trends in distance education. 


\section{Recommendations}

1. Tutors may be informed about system AIOU time to time.

2. Tutors may encourage the students so that they get motivation for future.

3. Tutors may be trained through institutions in the use of educational technology.

4. Refresher courses may be arranged for tutors where they discuss the existing structure of distance education and future of distance education.

5. Tutors may be trained in teaching techniques.

6. Tutors may involve community for distance education.

7. Tutors may be trained in advance courses of their related subjects.

\section{References}

Australian Teaching Council (1996). National Competency Framework for Beginning Teaching. Australia: Commonwealth of Australia, (pp-iii-iv).

Bernadette, Robinson.(1981)Support for student learning .London: Croomhelm

Gonczi, A. et al. (1990). Establishing competency-based standards in the professions, NOOSR Research Paper No.1, Australian Government Publishing Service (AGPS): Canberra.

Harris, W.J.A \& Williams (1977).A handbook of distance education Manchester: University

of Manchester

Kaur, Ambika .S (1996). Managing distance education . New Ddlhi. Deep and Deep Publication.

Messick, S. (1994). The Psychology of Educational Measurement. Journal of Educational Measurement, $15,297-300$.

Moore, M.G., and Kearsley, G. (1996). Distance Education: A systems View. Wadsworth Publishing Rumble, G \& Keegan, D.(1982). "In Introducation”. In Rumble, G and Harry,K. (Eds) 1982. The distance teaching universities .London.Croom-Helm.

Wedemeyer, C.A. (1983) Backdoor Learning in the Learning Society. In Sewart D. Keegan D. and Holmberg, B. (Eds) Distance Education International Perspective. London: Croom Helm. 